\title{
Changes in the Phytoremediation Potential of Indoor Plants with Exposure to Toluene
}

\author{
Kwang Jin Kim, Eun Ha Yoo, Myeong Il Jeong, Jeong Seob Song, \\ and Seung Youn Lee \\ Urban Agriculture Research Division, National Institute of Horticultural \\ and Herbal Science, Rural Development Administration, Suwon 441-440, \\ Korea
}

\author{
Stanley J. Kays ${ }^{1}$ \\ Department of Horticulture, 1111 Plant Sciences Building, University of \\ Georgia, Athens, GA 30602-7273
}

Additional index words. volatile organic compounds, VOCs, health

\begin{abstract}
Changes in phytoremediation efficiency after repeated exposures (three) to toluene (1.3 ppm) were assessed in 26 species and two additional cultivars of indoor plants. There was a rapid increase in toluene removal efficiency in 27 of the 28 crops with the greatest increase between the first and second exposure (i.e., after 3 days). The increase in efficiency between the first and third exposure ranged from 378 $\mu \mathrm{g} \cdot \mathrm{m}^{-3} \cdot \mathrm{h}^{-1} \cdot \mathrm{m}^{-2}$ leaf area in Pinus densiflora to -16.6 in Salvia elegans with a mean of 156 for all crops. Percent change ranged from 614 (Pittosporum tobira) to -8 (Salvia elegans) but was not necessarily indicative of phytoremediation value of a species. Rapid changes in phytoremediation efficiency in response to exposure to toluene appear to be widespread in plants and may be the result of an effect on gene expression in the plant and/or certain soil microbes or changes in the population density of toluenemetabolizing microbes. Increasing toluene removal efficiency is advantageous and as a consequence, a better understanding of the mechanism(s) operative may improve use of the response for practical applications.
\end{abstract}

Toluene is a common volatile organic compound (VOC) found in homes and offices that represents a serious health hazard. It is readily absorbed through the respiratory tract and to a lesser extent through the skin (EPA, 1990). Exposure is generally by way of contaminated air (CDC, 2010) with an individual's exposure strongly dependent on the indoor concentration (Chikara et al., 2009). Although toluene is not considered a carcinogen, exposure to high levels is known to affect the kidneys, nervous system, liver, brain, and heart. Short-term exposure of humans (100 ppm v/v or greater) has elicited central nervous system effects such as fatigue, confusion, poor coordination, and impairment of reaction time, perception, and motor control and function (NTP, 2000) in addition to poor performance on cognitive tests and eye and upper respiratory tract irritation (ATSDR, 2000). Health effects of lower concentrations are unknown but may result in confusion, lightheadedness, and other symptoms.

Household products from which toluene may emanate include cosmetics, rubber cement, nail polish solvent, stain removers, paint brush cleaners, fabric dyes, inks, adhesives,

\footnotetext{
Received for publication 3 Mar. 2011. Accepted for publication 26 Apr. 2011.

${ }^{1}$ To whom reprint requests should be addressed; e-mail kaysstan@uga.edu.
}

and cigarette smoke (ATSDR, 2000; Gordon et al., 1999). The threshold limit value (TLV) for toluene in homes, which is typically set by the government although not so in the United States, is $0.27 \mathrm{ppm} \mathrm{v} / \mathrm{v}\left(1000 \mu \mathrm{g} \cdot \mathrm{m}^{-3}\right)$ in Korea (Korean Ministry of Environment, 2006), $0.07 \mathrm{ppm}\left(260 \mu \mathrm{g} \cdot \mathrm{m}^{-3}\right)$ in Japan (Japanese Ministry of Health, Labour and Welfare, 2000), 20 ppm (time-weighted average) in the United States (ACGIH, 2008), and 100 ppm in Australia (NOHSC, 2001). Comparing the concentration of toluene between two cities in Korea [Asan (medium size) and Seoul (major metropolitan area)], the indoor concentrations averaged 17.3 to 170.7 $\mu \mathrm{g} \cdot \mathrm{m}^{-3}$, respectively (Son et al., 2003) and varied directly with the outdoor air concentration such that the indoor/outdoor ratios were approximately the same (1.12 to 1.03$)$. In Japan, higher indoor/outdoor ratios were common (i.e., 1.7 to 2.5 ) and varied with date of measurement (Chikara et al., 2009). In a nationwide survey in Korea, $40 \%$ of new apartments exceeded the upper limit for toluene and $50 \%$ exceeded that for benzene in the air (Korean Ministry of Environment, 2006).

A relatively small number of indoor plants have been shown to effectively remove a number of airborne VOCs that contaminate the environment (Kim et al., 2010; Wolverton and Takenaka, 2010; Yang et al., 2009). The pollutants may be metabolized by the plants but are also removed by microorganisms in the soil/media and through absorption or adsorption to the plant surface and the soil/media (Chun et al., 2010; Orwell et al., 2004; Son et al., 2000; Wolverton, 1986; Wolverton and Wolverton, 1993; Wood et al., 2002).

There appear to be changes in the plant's phytoremediation efficiency with exposure to VOCs (Kil et al., 2008; Orwell et al., 2004), although the mechanism(s) controlling the response is not known. Such changes in efficiency have only been demonstrated in a small number of plant species and VOCs to date. Inoculation using cultured bacterial populations from nine indoor plant species significantly increased the removal of a crosssection of benzenes (benzene, toluene, $m, p$ xylene, and $o$-xylene) (Chun et al., 2010). Microbe populations extracted from the media of certain plant species were more effective than others (Chamaedorea elegans $>$ Nephrolepis exaltata $>$ Sanservieria trifasciata) in the removal of VOCs and their removal efficiency varied with the volatile in question. Therefore, VOC-mediated changes in the microbe population may be a critical factor in alterations in phytoremediation efficiency; however, changes in plant gene expression have not been assessed.

To better understand the effect of exposure to VOCs on their subsequent removal, we assessed changes in toluene removal efficiency in 26 plant species.

\section{Materials and Methods}

Plant materials. A number of popular herbs and woody and herbaceous foliage plants in Korea were obtained from a commercial market (Table 1). The plants were transplanted into 30-, 19-, or 15-cm-diameter pots (depending on plant size) containing a uniform growing medium comprised of Mix \#4 (Sun Gro Horticulture, Bellevue, WA), bark-humus (Biocom. Co., Seoul, Korea), and sand at 5:1:1, v/v/v. Mix \#4 contained Canadian sphagnum peatmoss ( $55 \%$ to $65 \%$ by volume), perlite, dolomitic lime, gypsum, and a wetting agent. The plants were acclimated within simulated living rooms designed to create a typical indoor environment (Kim et al., 2009) for greater than 1 month $\left(23 \pm 2{ }^{\circ} \mathrm{C}, 40 \% \pm 5 \%\right.$ relative humidity). Light conditions were tailored to the plant type. Indoor foliage plants were acclimated at a light intensity of $20 \pm 2 \mu \mathrm{mol} \cdot \mathrm{m}^{-2} \cdot \mathrm{s}^{-1}$ and the herbs and woody foliage plants at $60 \pm 3 \mu \mathrm{mol} \cdot \mathrm{m}^{-2} \cdot \mathrm{s}^{-1}$ using fluorescent lights; the photoperiod for all species was $12 / 12 \mathrm{~h}$ (day/night). The plants were watered every $3 \mathrm{~d}$ with the excess water allowed to drain. All plants were watered the day before the gas treatments. Depending on pot diameter, one or two, five or six, or seven or eight pots [30, 19 , and $15 \mathrm{~cm}$ with media volumes of 1.6 , 2.2, and 12.6 (L), respectively] were placed in a chamber such that the total media volume per chamber was approximately the same (11 to $13 \mathrm{~L}$ ). Three replicates (chambers) of each species were tested. Control chambers without plants were used to 
Table 1. Indoor plants species tested and their height, fresh weight, leaf area, and number of pot plants per chamber.

\begin{tabular}{|c|c|c|c|c|c|c|}
\hline Type of plants & Latin binomial & Common name & $\begin{array}{l}\text { Plant ht } \\
(\mathrm{cm} / \mathrm{pot})\end{array}$ & $\begin{array}{l}\text { Fresh wt } \\
\text { (g/pot) }\end{array}$ & $\begin{array}{l}\text { Leaf area } \\
\left(\mathrm{cm}^{2} / \text { pot }\right)\end{array}$ & $\begin{array}{l}\text { No. of pot } \\
\text { plants per } \\
\text { chamber }\end{array}$ \\
\hline \multirow[t]{7}{*}{ Herbs } & Aloysia triphylla (L'Hér.) Britton² & Lemon Verbena & $14.6 \pm 0.1^{\mathrm{y}}$ & $11.7 \pm 0.2$ & $348.4 \pm 4.1$ & $5^{\mathrm{x}}$ \\
\hline & Melissa officinalis L. & Lemon balm & $14.6 \pm 0.2$ & $45.5 \pm 0.7$ & $1644.5 \pm 40.7$ & 5 \\
\hline & Mentha piperita L. 'Citrata' & Eau-de-cologne mint & $13.3 \pm 0.3$ & $61.6 \pm 0.8$ & $1665.5 \pm 88.6$ & 5 \\
\hline & Mentha suaveolens Ehrh. & Apple mint & $16.7 \pm 0.3$ & $32.2 \pm 0.7$ & $500.1 \pm 16.0$ & 8 \\
\hline & Mentha suaveolens Ehrh. Variegata & Pineapple mint & $11.6 \pm 0.1$ & $31.5 \pm 0.6$ & $642.4 \pm 18.2$ & 7 \\
\hline & Rosmarinus officinalis $\mathrm{L}$. & Rosemary & $20.9 \pm 0.1$ & $56.1 \pm 0.8$ & $673.0 \pm 10.3$ & 7 \\
\hline & Salvia elegans Vahl & Pineapple sage & $59.3 \pm 1.3$ & $86.4 \pm 3.3$ & $1672.9 \pm 89.0$ & 5 \\
\hline \multirow{3}{*}{$\begin{array}{l}\text { Herbaceous } \\
\text { foliage plants }\end{array}$} & Begonia maculata Raddi & Cane begonia & $51.2 \pm 0.0$ & $395.4 \pm 1.3$ & $3822.7 \pm 39.9$ & 5 \\
\hline & Davallia mariesii Moore ex Baker & Squirrels-foot fern & $18.2 \pm 0.2$ & $50.9 \pm 0.5$ & $1247.0 \pm 34.4$ & 7 \\
\hline & Farfugium japonicum (L.) Kitam. & Leopard plant & $17.4 \pm 0.1$ & $92.4 \pm 3.5$ & $1705.5 \pm 66.3$ & 5 \\
\hline \multirow{11}{*}{$\begin{array}{l}\text { Woody } \\
\text { foliage plants }\end{array}$} & Ardisia crenata Sims. & Coralberry & $48.5 \pm 0.2$ & $141.6 \pm 0.5$ & $2582.7 \pm 37.2$ & 5 \\
\hline & Ardisia japonica (Thunb.) Blume & Marberry & $16.5 \pm 0.1$ & $20.1 \pm 0.2$ & $480.0 \pm 9.6$ & 5 \\
\hline & Ardisia pusilla A.DC. & Japanese ardisia & $28.3 \pm 0.1$ & $84.0 \pm 1.0$ & $2489.7 \pm 40.0$ & 8 \\
\hline & Cinnamomum camphora (L.) J. Presl & Camphor tree & $87.5 \pm 0.3$ & $421.3 \pm 8.5$ & $6864.0 \pm 185.1$ & 1 \\
\hline & $\begin{array}{l}\text { Schefflera elegantissima (Veitch ex } \\
\text { Masters) Lowry \& Frodin }\end{array}$ & False Aralia & $58.2 \pm 0.9$ & $142.9 \pm 1.7$ & $2944.6 \pm 35.5$ & 5 \\
\hline & Eurya emarginata (Thunb.) Makino & Emarginate Eurya & $79.3 \pm 0.6$ & $479.0 \pm 22.6$ & $4653.9 \pm 91.6$ & 2 \\
\hline & Ilex cornuta Lindl. \& Paxton & Chinese holly & $98.7 \pm 2.7$ & $344.9 \pm 16.8$ & $3291.2 \pm 265.4$ & 2 \\
\hline & Ligustrum japonicum Thunb. & Wax leaf privet & $80.7 \pm 0.6$ & $403.9 \pm 19.1$ & $6195.6 \pm 313.2$ & 1 \\
\hline & Pinus densiflora Siebold \& Zucc. & Japanese red pine & $29.9 \pm 0.2$ & $60.3 \pm 0.6$ & $269.7 \pm 6.8$ & 7 \\
\hline & Pittosporum tobira (Thunb.) W.T.Aiton & Japanese pittosporum & $91.0 \pm 1.1$ & $927.9 \pm 56.7$ & $7790.7 \pm 345.8$ & 1 \\
\hline & Rhododendron fauriei Franch. & Fujiyama rhododendron & $24.8 \pm 0.4$ & $24.9 \pm 1.1$ & $506.5 \pm 23.3$ & 5 \\
\hline
\end{tabular}

2Plant name source: http://www.theplantlist.org/.

${ }^{y}$ Data are means \pm SE $(n=15)$.

${ }^{\mathrm{x}}$ The number of pot plants in a chamber depended on pot size: $1-2,5-6$, and 7-8 pot plants were 30-, 19- and 15-cm-diameter pots, respectively.

determine toluene losses not resulting from the plants (e.g., leakage, adsorption, chemical reactions). Plant height was measured and leaf area was determined using a LI-3100 area meter (LI-COR Inc., Lincoln, NE) at the end of the experiment (Table 1).

Treatment system. The treatment system consisted of controlled environment rooms, test chambers, and a gas generator. The environment rooms in which the test chambers were placed controlled the temperature, light intensity, and relative humidity. The test chambers were made of inert materials (i.e., glass surfaces, stainless steel frame, and Teflon) that were impermeable to VOCs. Chamber doors were sealed using an adhesive closed-pore neoprene foam tape and adjustable metal clips. The volume of each chamber was $1.0 \mathrm{~m}^{3}(90 \mathrm{~cm}$ wide $\times 90 \mathrm{~cm}$ long $\times 123 \mathrm{~cm}$ high), equal to approximately half the volume of a personal breathing zone. Using a sealed external pump, the interior air was circulated $\left(6 \mathrm{~L} \cdot \mathrm{min}^{-1}\right)$ and released at the bottom of the chamber through a stainless steel tube $(0.64 \mathrm{~cm}$ i.d. $)$ with holes. The concentration of toluene was determined on samples collected at three heights within the chambers (i.e., 12,70 , and $98 \mathrm{~cm}$ from the bottom of the chamber).

Gas exposure and measurement. We developed a gas generator that converted VOC solutions to volatiles. The gaseous toluene was collected in a sealed Teflon bag and $\approx 1.2 \mathrm{~L}$ was introduced into each test chamber using a quantitative pump (MP- $\Sigma$; Sibata Co., Soka-City, Saitama, Japan). To compensate for the differential in air pressure, 1.2 $\mathrm{L}$ of air was removed from the chamber using a second air pump before gas injection. The toluene gas was mixed within the chamber for 15 min using the chamber air circulation system. The internal concentration was determined and corrected to $\approx 5000$ $\mu \mathrm{g} \cdot \mathrm{m}^{-3}(1.3 \mathrm{ppm})$. The concentration was determined every $3 \mathrm{~h}$ for $18 \mathrm{~h}$ during the test after being allowed to stabilize for $15 \mathrm{~min}$. After the plants were exposed to gaseous toluene, they were held in fresh air in the simulated living room for $2 \mathrm{~d}$ until next exposure. Control chambers devoid of plants were treated similarly to determine gas losses. During the tests, the plants were exposed to the same light source and intensity used for acclimation.

Thermal desorption. A quartz cold trap [120 mm long, $2.9 \mathrm{~mm}$ o.d., $1.0 \mathrm{~mm}$ i.d. (inlet), $2.0 \mathrm{~mm}$ i.d. (outlet); Markes International Ltd., Llantrisant, U.K.] was connected to each chamber and an air sample collected for $5 \mathrm{~min}$ at $5 \mathrm{~mL} \cdot \mathrm{min}^{-1}$. An automated thermal desorption system with an Air Server autosampler (UNITY; Markes Internation- al Ltd., U.K.) was connected to the injection port of the gas chromatography-mass spectrometer (TRACE DSQ; Thermo Electron Co., Waltham, MA). Toluene was cryofocused at $5{ }^{\circ} \mathrm{C}$ for $5 \mathrm{~min}$, desorbed at $280{ }^{\circ} \mathrm{C}$, and separated using a ZB-624 capillary column $(30-\mathrm{m}$ length $\times 0.25-\mathrm{mm}$ i.d., $1.40-\mu \mathrm{m}$ film thickness of $6 \%$ cyanopropylphenyl, 94\% dimethylpolysiloxane; Phenomenex, Torrance, CA). The injection port temperature was $180^{\circ} \mathrm{C}$ with a split ratio of $29: 1$. Helium was used as the carrier gas at a flow rate of $1.0 \mathrm{~mL} \cdot \mathrm{min}^{-1}$. The column temperature was held at $45^{\circ} \mathrm{C}$ for $1 \mathrm{~min}$ and increased at a rate of $15{ }^{\circ} \mathrm{C} \cdot \mathrm{min}^{-1}$ to $100{ }^{\circ} \mathrm{C}$ and held for $1 \mathrm{~min}$ and then increased at a rate of $5^{\circ} \mathrm{C} \cdot \mathrm{min}^{-1}$ to $135^{\circ} \mathrm{C}$.

Data analysis. Gas concentrations were expressed as $\mu \mathrm{g} \cdot \mathrm{m}^{-3}$ and the data were normalized to $24 \pm 1{ }^{\circ} \mathrm{C}$ and $100 \mathrm{kPa}$ (Hines et al., 1993). Data were expressed as the average of three replicates. The accumulated removal of toluene [Eq. 1] and the removal efficiency per unit leaf area [Eq. 2] were calculated (Kim et al., 2008) as:

(a)

Accumulated removal $=$

$[(\mathrm{Pi}-(\mathrm{Ci}-\mathrm{C}))-\mathrm{P}] \times(\mathrm{F} \times \mathrm{CV}) / \mathrm{L} \quad[1]$ 
(b)

$$
\begin{aligned}
& \text { Removal efficiency }= \\
& \quad[(\mathrm{Pi}-(\mathrm{Ci}-\mathrm{C}))-\mathrm{P}] \times(\mathrm{F} \times \mathrm{CV}) /(\mathrm{L} \times \mathrm{T})
\end{aligned}
$$

where $\mathrm{P}$ is the gas concentration measured in a chamber with plants $\left(\mu \mathrm{L} \cdot \mathrm{L}^{-1}\right)$; Pi the initial gas concentration measured in a chamber with plants $\left(\mu \mathrm{L} \cdot \mathrm{L}^{-1}\right)$; $\mathrm{C}$ the gas concentration measured in a chamber without plants $\left(\mu \mathrm{L} \cdot \mathrm{L}^{-1}\right)$; $\mathrm{Ci}$ the initial gas concentration measured in a chamber without plants $\left(\mu \mathrm{L} \cdot \mathrm{L}^{-1}\right) ; \mathrm{F}$ the toluene conversion factor for volume $\left(\mu \mathrm{L} \cdot \mathrm{L}^{-1}\right)$ to mass $\left(\mathrm{mg} \cdot \mathrm{m}^{-3}\right) ; \mathrm{CV}$ the volume of the chamber $\left(\mathrm{m}^{3}\right)$; L the total leaf area per chamber $\left(\mathrm{m}^{2}\right)$; and $\mathrm{T}$ the gas exposure time (h).

The loss of toluene $(\mathrm{Ci}-\mathrm{C})$ not resulting from the plant and media was determined using empty chambers.

\section{Results and Discussion}

Changes in the phytoremediation efficiency with exposure to toluene were assessed in a diverse cross-section of species (Table 1). Included were 26 species with an additional cultivar for two species for a total of 28 species/cultivars. Plant types included seven herbaceous foliage plants, 10 herbs, and 11 woody foliage plants. Exposure of the plants to toluene resulted in an increase in subsequent toluene removal efficiency (Fig. 1). In most instances, the greatest increase in efficiency occurred between the first and second exposures with the rate of increase decreasing appreciably between the second and third exposures. The rate of removal varied among species as did the magnitude of the increase in efficiency. Removal efficiency did not increase with additional exposures to toluene (up to nine exposures) in a subset of the species tested (data not shown).

Contrasting the change in toluene removal rate (third exposure - first exposure), the actual change ranged from an increase of $378 \mu \mathrm{g} \cdot \mathrm{m}^{-3} \cdot \mathrm{h}^{-1} \cdot \mathrm{m}^{-2}$ leaf area in Pinus densiflora to a decrease of 16.6 in Salvia elegans with a mean of 156 (Table 2). Of the 28 different species/cultivars tested, 27 were observed to increase toluene removal rate after the initial exposure; only one had a decreased removal rate after the first exposure. Expressed as the mean increase in efficiency, the mean for all test plants was $122 \%$. The percent change was not necessarily indicative of the phytoremediation value of a species because some species with a very high percent change (e.g., Pittosporum tobira, 614\%) had a very small actual change in toluene removal rate $\left(26.4 \mu \mathrm{g} \cdot \mathrm{m}^{-3} \cdot \mathrm{h}^{-1} \cdot \mathrm{m}^{-2}\right.$ leaf area). Likewise, the species with the highest change in toluene removal rate (Pinus densiflora, $\left.378 \mu \mathrm{g} \cdot \mathrm{m}^{-3} \cdot \mathrm{h}^{-1} \cdot \mathrm{m}^{-2}\right)$ had a relatively low percent change $(70 \%)$ from the first to the third exposure.

Comparing the increase in toluene removal efficiency based on the general plant

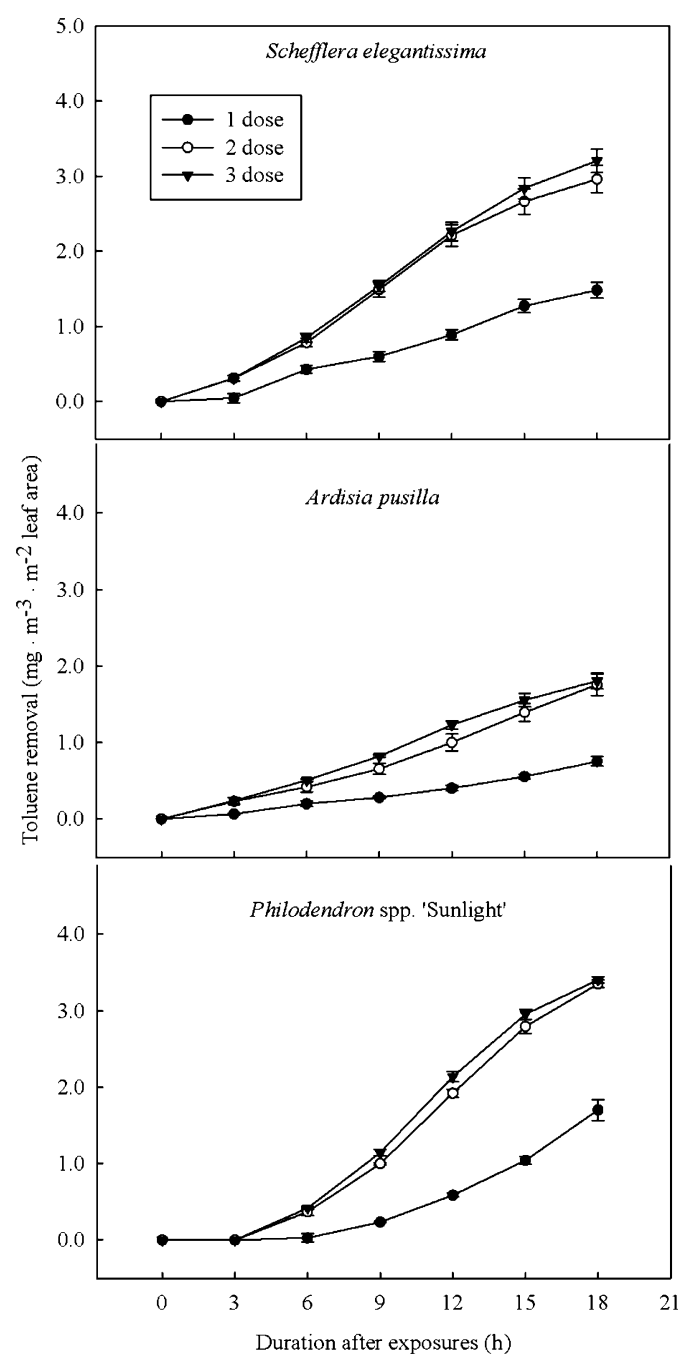

Fig. 1. Changes in toluene removal rate by potted indoor plants with exposure time and the number of exposures. The initial concentration of gaseous toluene was $\approx 5 \mathrm{mg} \cdot \mathrm{m}^{-3}$ and the plants were exposed for $18 \mathrm{~h}$ in sealed chambers at a light intensity of $20 \pm 2 \mu \mathrm{mol} \cdot \mathrm{m}^{-2} \cdot \mathrm{s}^{-1}$. Vertical bars denote the SE.

type (Table 3), woody foliage plants had the greatest mean increase in removal rate (159 $\mu \mathrm{g} \cdot \mathrm{m}^{-3} \cdot \mathrm{h}^{-1} \cdot \mathrm{m}^{-2}$ leaf area) and herbaceous foliage plants the least $\left(71 \mu \mathrm{g} \cdot \mathrm{m}^{-3} \cdot \mathrm{h}^{-1} \cdot \mathrm{m}^{-2}\right.$ leaf area); herbs were intermediate between the two $\left(118 \mu \mathrm{g} \cdot \mathrm{m}^{-3} \cdot \mathrm{h}^{-1} \cdot \mathrm{m}^{-2}\right.$ leaf area). Woody foliage plants also had the widest range in toluene removal rate between the lowest and highest species (Pittosporum tobira and Pinus densiflora, respectively). Herbs were very similar but slightly lower (i.e., Pelargonium graveolens vs. Salvia elegans differed by $320 \mu \mathrm{g} \cdot \mathrm{m}^{-3} \cdot \mathrm{h}^{-1} \cdot \mathrm{m}^{-2}$ leaf area). Herbaceous foliage plants displayed the narrowest range $\left(125 \mu \mathrm{g} \cdot \mathrm{m}^{-3} \cdot \mathrm{h}^{-1} \cdot \mathrm{m}^{-2}\right.$ leaf area) and lowest mean change in rate $\left(71 \mu \mathrm{g} \cdot \mathrm{m}^{-3} \cdot \mathrm{h}^{-1} \cdot \mathrm{m}^{-2}\right.$ leaf area $)$.

Exposure to toluene results in a quite rapid (i.e., less than $3 \mathrm{~d}$ ) increase in toluene removal efficiency after the initial exposure. The response appears to be widespread in the plant kingdom with 27 of 28 of the test species/cultivars increasing their rate of toluene removal. However, it has been demonstrated that microbes within the growing media are also involved in the removal of VOCs (Kil et al., 2008; Orwell et al., 2004) in addition to the live plant. As a consequence, increases in efficiency may have been attributable to an effect on certain microorganism species in the media. The observed increases in efficiency could have been mediated through an effect on particular sectors of the microbe population and/or the plant itself through altered gene expression. It could also be the result of a change in the population of microbes that effectively metabolize toluene and presumably derive a benefit from its presence. The rapid rate of increase in toluene removal efficiency over $3 \mathrm{~d}$ is likely greater than the increase in beneficial microbe populations could account for, i.e., in some instances, up to a six times increase in efficiency. Regardless of the cause, increasing toluene removal efficiency is advantageous to the phytoremediation process in general and a better understanding of the mechanism(s) responsible for this increase may enable end-users to take full advantage of the response. 
Table 2. Toluene removal efficiency and its change according to the number of exposures.

\begin{tabular}{|c|c|c|c|c|c|}
\hline \multirow[b]{3}{*}{ Plant species } & \multicolumn{4}{|c|}{ Toluene removal $\left(\mu \mathrm{g} \cdot \mathrm{m}^{-3} \cdot \mathrm{h}^{-1} \cdot \mathrm{m}^{-2}\right.$ leaf area $)$} & \multirow{3}{*}{$\begin{array}{c}\text { Change } \\
(\%)\end{array}$} \\
\hline & \multicolumn{3}{|c|}{ Number of exposure } & \multirow{2}{*}{$\frac{\Delta \text { rate }}{3-1}$} & \\
\hline & 1 & 2 & 3 & & \\
\hline Pinus densiflora & $541.5 \pm 80.3^{z}$ & $623.3 \pm 89.1$ & $919.7 \pm 89.9$ & 378.2 & 69.8 \\
\hline Ilex cornuta & $62.4 \pm 14.7$ & $299.4 \pm 56.4$ & $429.7 \pm 104.5$ & 367.3 & 589.0 \\
\hline Pelargonium graveolens & $206.5 \pm 22.2$ & $549.6 \pm 50.1$ & $510.3 \pm 78.1$ & 303.7 & 147.1 \\
\hline Ardisia japonica & $231.2 \pm 5.3$ & $384.6 \pm 38.6$ & $500.1 \pm 47.2$ & 268.9 & 116.3 \\
\hline Mentha $\times$ piperita & $258.4 \pm 9.0$ & $469.8 \pm 9.9$ & $440.6 \pm 20.4$ & 182.2 & 70.5 \\
\hline Mentha suaveolens & $564.8 \pm 45.3$ & $682.1 \pm 66.8$ & $733.7 \pm 55.7$ & 168.9 & 29.9 \\
\hline Mentha suaveolens 'Variegata' & $258.3 \pm 25.6$ & $442.5 \pm 26.2$ & $422.9 \pm 13.6$ & 164.6 & 63.7 \\
\hline Rhododendron fauriei & $767.4 \pm 133.7$ & $950.3 \pm 131.5$ & $928.3 \pm 1$ & 160.9 & 21.0 \\
\hline emarginata & $60.0 \pm 8.3$ & $190.1 \pm 26.1$ & $213.7 \pm 24.4$ & 153.7 & 256.3 \\
\hline Ligustrum japonicum & $111.0 \pm 40.3$ & $176.3 \pm 6.2$ & $250.9 \pm 4.6$ & 139.8 & 125.9 \\
\hline Fittonia verschaffeltii & $316.7 \pm 60.7$ & $522.2 \pm 37.7$ & $449.8 \pm 31.9$ & 133.0 & 42.0 \\
\hline camphora & $23.8 \pm 49.7$ & $203.8 \pm 48.4$ & $244.1 \pm 45.7$ & 120.4 & 97.2 \\
\hline Aloy & $643.2 \pm 9.3$ & $755.6 \pm 5.7$ & $761.4 \pm 3.6$ & 118.2 & 18.4 \\
\hline perita 'Citrata' & $95.7 \pm 1.1$ & $157.9 \pm 2$ & $209.9 \pm 10.4$ & 114.2 & 119.3 \\
\hline ariesii & $90.1 \pm 8.5$ & $134.0 \pm 10.2$ & $190.7 \pm 21.1$ & 100.6 & 111.6 \\
\hline Farfugium japonicum & $147.4 \pm 20.3$ & $224.3 \pm 22.5$ & $245.5 \pm 23.5$ & 98.1 & 66.6 \\
\hline Schefflera elegantissima & $86.8 \pm 8.6$ & $163.9 \pm 24.3$ & $174.6 \pm 19.9$ & 87.8 & 101.1 \\
\hline Ardisia crenata & $37.7 \pm 4.2$ & $83.6 \pm 0.6$ & $114.1 \pm 5.0$ & 76.4 & 202.7 \\
\hline ficinalis & $483.2 \pm 29.6$ & $569.8 \pm 47.5$ & $558.7 \pm 84.7$ & 75.5 & 15.6 \\
\hline Soleirolia soleirolii & $181.3 \pm 4.2$ & $340.3 \pm 1.2$ & $254.0 \pm 12.0$ & 72.8 & 40.2 \\
\hline Philodendron spp. 'Sunlight' & $131.9 \pm 10.7$ & $178.3 \pm 4.0$ & $183.8 \pm 2.8$ & 51.9 & 39.4 \\
\hline Ardisia pusilla & $41.5 \pm 3.4$ & $84.5 \pm 6.9$ & $88.6 \pm 5.2$ & 47.1 & 113.5 \\
\hline Hedera helix & $368.1 \pm 30.3$ & $355.2 \pm 21.3$ & $401.0 \pm 33.5$ & 32.9 & 8.9 \\
\hline Melissa officinalis & $187.9 \pm 48.7$ & $171.9 \pm 15.7$ & $218.7 \pm 18.8$ & 30.8 & 16.4 \\
\hline Plectranthus tomentosus & $78.0 \pm 23.0$ & $90.4 \pm 18.4$ & $108.6 \pm 22.3$ & 30.5 & 39.1 \\
\hline Pittosporum tobira & $-4.3 \pm 6.7$ & $1.6 \pm 0.2$ & $22.1 \pm 5.3$ & 26.4 & 613.8 \\
\hline Begonia maculate & $47.8 \pm 11.4$ & $64.7 \pm 7.0$ & $55.9 \pm 1.8$ & 8.2 & 17.1 \\
\hline Salvia elegans & $205.1 \pm 12.3$ & $185.0 \pm 3.3$ & $188.4 \pm 1.8$ & -16.6 & -8.1 \\
\hline
\end{tabular}

${ }^{\mathrm{z}}$ Data are means \pm SE $(\mathrm{n}=15)$.

Table 3. Effect of plant type on the change in rate of toluene removal with previous exposure to the gas $(\Delta$ rate $=$ third exposure - first exposure $)$ and the mean rate of toluene removal from the air.

\begin{tabular}{lrcccc}
\hline & \multicolumn{3}{c}{ Rate of toluene removal $\left(\mu \mathrm{g} \cdot \mathrm{m}^{-3} \cdot \mathrm{h}^{-1} \cdot \mathrm{m}^{-2}\right.$ leaf area $)$} \\
\cline { 2 - 3 } \cline { 6 - 6 } Type of plants & \multicolumn{2}{c}{$\Delta$ rate } & & \multicolumn{2}{c}{ Third exposure } \\
\cline { 2 - 3 } \cline { 6 - 7 } & Mean & Range & & Mean & Range \\
Woody foliage plants & 158.7 & $378.2-26.4$ & & 351.5 & $929.3-22.1$ \\
Herbs & 117.5 & 303.7 to -16.6 & & 376.9 & $733.7-108.6$ \\
Herbaceous foliage plants & 71.1 & $133.0-8.2$ & & 254.4 & $449.8-55.9$ \\
\hline
\end{tabular}

\section{Literature Cited}

ACGIH. 2008. Threshold limit values for chemical substances and physical agents and biological exposure indices. American Conference of Industrial Hygienists, Signature Pub., Cincinnati, $\mathrm{OH}$.

ATSDR. 2000. Toxicological profile for toluene. Agency for Toxic Substance and Disease Registry, Atlanta, GA.

CDC. 2010. National report on human exposure to environmental chemicals. Toluene. Centers for Disease Control and Prevention. <http://www. doc.cdc.gov/ exposurereport/data_tables/Toluene ChemicalInformation.html $>$.

Chikara, H., S. Iwamoto, and T. Yoshimura. 2009. Indoor air pollution of volatile organic compounds-Indoor/outdoor concentrations, sources and exposures. Nippon Eiseigaku Zasshi 64 : 683-688.

Chun, S.-C., M.H. Yoo, Y.S. Moon, M.H. Shin, K.-C. Son, I.-M. Chung, and S.J. Kays. 2010. Effect of bacterial population from rhizosphere of various foliage plants on removal of indoor volatile organic compounds. Kor. J. Hort. Sci. Technol. 28:476-483.

EPA. 1990. Drinking water criteria document for toluene. Environmental Assessment Office, Office of Health and Environmental Assessment, U.S. Environmental Protection Agency, Cincinnati, $\mathrm{OH}$

Gordon, S.M., P.J. Callahan, M.G. Nishioka, M.C Brinkman, M.K. O'Rourke, M.D. Lebowitz, and D.J. Moschandreas. 1999. Residential environmental measurements in the National Human Exposure Assessment Survey (NHEXAS) pilot study in Arizona: preliminary results for pesticides and VOCs. J. Exposure Analysis Environ. Epidemiology 9:456-470.

Hines, A.L., T.K. Ghosh, S.K. Loylka, and R.C. Warder, Jr. 1993. Indoor air: Quality and control. Prentice Hall, Englewood Cliffs, N.J.

Japanese Ministry of Health, Labour and Welfare. 2000. <http://www.mhlw.go.jp/houdou/2002/02/ ho208-3.html>

Kil, M.J., K.J. Kim, C.H. Pak, H.H. Kim, and Y.W. Lim. 2008. Effects of growing media and exposure frequency on the volatile formaldehyde removal in potted Epipremnum aureum. Kor. J. Hort. Sci. Technol 26:325-330.

Kim, K.J., M.I. Jeong, D.W. Lee, J.S. Song, H.D. Kim, E.H. Yoo, S.J. Jeong, S.Y. Lee, S.J. Kays, Y.W. Lim, and H.H. Kim. 2010. Variation in formaldehyde removal efficiency among indoor plant species. HortScience 45:14891495.

Kim, K.J., M.J. Kil, M.I. Jeong, H.D. Kim, E.H. Yoo, S.J. Jeong, C.H. Pak, and K.C. Son. 2009. Determination of the efficiency of formaldehyde removal according to the percentage volume of pot plants occupying a room. Kor. J. Hort. Sci. Technol. 27:305-311.

Kim, K.J., M.J. Kil, J.S. Song, E.H. Yoo, K.C. Son, and S.J. Kays. 2008. Efficiency of volatile formaldehyde removal by indoor plants: Contribution of aerial plant parts versus the root-zone. J. Amer. Soc. Hort. Sci. 133:521-526.

Korean Ministry of Environment. 2006. Recommended standards for indoor air quality for new apartments. Green Korea, Ministry of Environment, Republic of Korea, Seoul, Korea. p. 59-60.

NOHSC. 2001. Air toxics and indoor air quality in Australia. National Occupational Health and Safety Commission. <http://www.environment. gov.au/atmosphere/airquality/publications/sok/ toluene.html>.

NTP. 2000. Toxicology and carcinogenesis studies of toluene in $\mathrm{F} 344 / \mathrm{N}$ rats and $\mathrm{B}_{6} \mathrm{C}_{3} \mathrm{~F}_{1}$ mice (inhalation studies). Technical Rept. Series No. 371. National Toxicology Program, National Institutes of Health, U.S. Department of Health and Human Service, Public Health Service, Research Triangle Park, NC.

Orwell, R., R. Wood, J. Tarran, F. Torpy, and M. Burchett. 2004. Removal of benzene by the indoor plant/substrate microcosm and implications for air quality. Water Soil and Air Pollution 157:193-207.

Son, B., P. Breysse, and W. Yang. 2003. Volatile organic compounds concentrations in residential indoor and outdoor and its personal exposure in Korea. Environ. Int. 29:79-85.

Son, K.C., S.H. Lee, S.G. Seo, and J.E. Song. 2000. Effects of foliage plants and potting soil on the absorption and adsorption of indoor air pollutants. J. Korean Soc. Hort. Sci. 41:305310

Wolverton, B.C. 1986. Houseplants, indoor air pollutants, and allergic reactions. Rept. National Aeronautics Space Administration, Stennis Space Center, MS.

Wolverton, B.C. and K. Takenaka. 2010. Plants. Why you can't live without them. Lustre Press, New Delhi, India.

Wolverton, B.C. and J.D. Wolverton. 1993. Plants and soil microorganisms: Removal of formaldehyde, xylene, and ammonia from the indoor environment. J. Miss. Acad. Sci. 38:11-15.

Wood, R.A., R.L. Orwell, J. Tarran, F. Torpy, and M. Burchett. 2002. Potted-plant/growth media interactions and capacities for removal of volatiles from indoor air. J. Hortic. Sci. Biotechnol. 77:120-129.

Yang, D.S., S.V. Pennisi, K.C. Son, and S.J. Kays. 2009. Screening indoor plants for volatile organic pollutant removal efficiency. HortScience 44:1377-1381. 